\title{
In vitro characterization of AA71, a potent and selective human monoclonal antibody against CGRP receptor
}

\author{
L Shi', S Rao, H Sun, K Wild, C Xu \\ From The European Headache and Migraine Trust International Congress \\ London, UK. 20-23 September 2012
}

\section{Objectives}

To characterize the in vitro pharmacological properties of AA71, a human monoclonal antibody against the CGRP receptor.

\section{Introduction}

Calcitonin gene-related peptide (CGRP) is a neuropeptide that plays a key role in the pathophysiology of migraine. Clinical studies have demonstrated that CGRP receptor antagonism is an effective approach in treating acute migraine pain. We have previously reported the successful generation of a group of human monoclonal antibodies (MAb) that specifically target the human CGRP receptor (1). In our present study, we detail the characterization of AA71, a potent and selective human monoclonal antibody against the CGRP receptor.

\section{Results}

AA71 potently competed with the binding of [125I]-CGRP to the human CGRP receptor with a Ki of $0.03 \mathrm{nM}$. AA71 fully inhibited CGRP-stimulated cAMP production with an IC50 of $2 \mathrm{nM}$ in cell-based functional assays, with no intrinsic agonist activity up to $10 f$ ÝM. Functional potency of AA71 at the cyno CGRP receptor was similar to that at the human receptor with an IC50 of $4.5 \mathrm{nM}$, but potency at dog, rabbit and rat receptors was significantly reduced (>5000-fold). AA71 also demonstrated $>5000$-fold selectivity over other closely related receptors in the family. Through a saturation analysis using SK-N-MC membrane preparations, [125I]-AA71 was shown to bind the CGRP receptor in a monophasic and saturable fashion with a $\mathrm{Kd}$ of $0.08 \mathrm{nM}$. The binding of $0.1 \mathrm{nM}$ [125I]-AA71 to the CGRP receptor reached equilibrium at approximately

Department of Neuroscience, Amgen, Inc. Thousand Oaks, California, USA
$240 \mathrm{~min}$. A prolonged dissociation of [125I]-AA71 binding from the CGRP receptor was observed with a dissociation t1/2 off of $267 \mathrm{~min}$. In a competition study, CGRP is capability of displacing [125I]-AA71 binding is significantly less robust, with an observed Ki of $370 \mathrm{nM}$.

\section{Conclusion}

AA71 is a potent and selective antibody against the human CGRP receptor with potential for use in the treatment of migraine pain.

Published: 21 February 2013

\section{Reference}

1. Shi, et al:. International Headache Congress 2011.

doi:10.1186/1129-2377-14-S1-P183

Cite this article as: Shi et al:: In vitro characterization of AA71, a potent and selective human monoclonal antibody against CGRP receptor. The Journal of Headache and Pain 2013 14(Suppl 1):P183.

Submit your manuscript to a SpringerOpen ${ }^{\circ}$ journal and benefit from:

- Convenient online submission

- Rigorous peer review

- Immediate publication on acceptance

- Open access: articles freely available online

- High visibility within the field

- Retaining the copyright to your article

Submit your next manuscript at $>$ springeropen.com 